\title{
Inter-population differences in otolith morphology are genetically encoded in the killifish Aphanius fasciatus (Cyprinodontiformes)
}

\author{
ALI ANNABI ${ }^{1}$, KHALED SAID ${ }^{1}$ and BETTINA REICHENBACHER ${ }^{2}$ \\ ${ }^{1}$ Laboratoire de Recherche: Génétique, Biodiversité et Valorisation des Bioressources (LR 11/ES 41), Institut Supérieur \\ de Biotechnologie de Monastir, Université de Monastir, Tunisie. \\ ${ }^{2}$ Department of Earth and Environmental Sciences, Palaeontology and Geobiology, Ludwig-Maximilians-University \\ Munich, Richard-Wagner-Str. 10, 80333 Munich, Germany.E-mail: b.reichenbacher@lrz.uni-muenchen.de
}

\begin{abstract}
SUMMARY: Inter-population differences in otolith shape, morphology and chemistry have been used effectively as indicators for stock assessment or for recognizing environmental adaptation in fishes. However, the precise parameters that affect otolith morphology remain incompletely understood. Here we provide the first direct support for the hypothesis that inter-population differences in otolith morphology are genetically encoded. The study is based on otolith morphology and two mitochondrial markers (D-loop, 16S rRNA) of three natural populations of Aphanius fasciatus (Teleostei: Cyprinodontidae) from Southeast Tunisia. Otolith and genetic data yielded congruent tree topologies. Divergence of populations likely results from isolation events in the course of the Pleistocene sea level drops. We propose that otolith morphology is a valuable tool for resolving genetic diversity also within other teleost species, which may be important for ecosystem management and conservation of genetic diversity. As reconstructions of ancient teleost fish faunas are often solely based on fossil otoliths, our discoveries may also lead to a new approach to research in palaeontology.
\end{abstract}

Keywords: Cyprinodontidae, phylogeography, gene flow, local adaptation, otolith morphometry, mitochondrial markers.

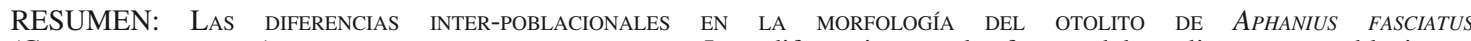
(CYPRINODONTIFORMES) SE CODIFICAN GENÉTICAMENTE. - Las diferencias en la forma del otolito entre poblaciones, la morfología o la química se han utilizado con efectividad como indicadores para la gestión de poblaciones o para el reconocimiento de adaptaciones ambientales en peces. Sin embargo, los parámetros precisos que afectan la morfología del otolito permanecen sin ser entendidos completamente. Aquí nosotros presentamos la primera evidencia directa para la hipótesis de que las diferencias inter-poblacionales en la morfología del otolito están codificadas genéticamente. El estudio se basa en la morfología del otolito y dos marcadores mitocondriales (D-loop, 16S rRNA) de tres poblaciones naturales de Aphanius fasciatus (Teleostei: Cyprinodontidae) del sudeste de Tunez. Los datos de otolitos y genéticos ofrecen tres topologías congruentes. Aparentemente la divergencia entre poblaciones resulta de los procesos de aislamiento durante los descensos del nivel del mar en el Pleistoceno. Proponemos que la morfología del otolito es una herramienta muy valiosa para entender la diversidad genética también con otras especies de peces, que puede ser importante para la gestión de los ecosistemas y la conservación de la diversidad genética. Ya que las reconstrucciones de la fauna antigua de peces teleósteos se basan a menudo en otolitos fósiles, nuestro hallazgo puede también ser importante como nueva aproximación en las investigaciones palentológicas.

Palabras clave: Cyprinodontidae, filogeografía, flujo génico, adaptación local, otolito, morfometría, marcador mitocondrial.

\section{INTRODUCTION}

Otoliths are aragonitic mineralizations that are arranged in three pairs in the inner ear of teleost fishes, where they play an important role in the senses of hearing and balance (Popper et al. 2005). The saccular otoliths (termed otoliths in the following) provide morphological characters that can be used in family, genus, and species discrimination (e.g. Smale et al. 1995, Volpedo and Echeverría 2000, Tuset et al. 
2008). In addition, otoliths can be found abundantly as fossils and are used to reconstruct ancient teleost fish diversity, zoogeography and evolution (e.g. Nolf 1995, Girone and Nolf 2009, Schwarzhans and Bratishko 2011).

Inter-population variability is known to occur widely in otoliths, especially with regard to size and contour, daily and annual growth rings, trace elements, and isotopic compositions. Fourier analysis and landmarks have been used to quantify otolith variation (size and contour) between species, populations, and even stocks (e.g. Castonguay et al. 1991, Torres et al. 2000, Monteiro et al. 2005, Mérigot et al. 2007). Differences in otolith chemistry have been used for stock discrimination, analyses of population structure, reconstruction of the environmental history, and ecosystem monitoring (e.g. Campana 1999, Volpedo and Cirelli 2006, Woods et al. 2010). However, only a few studies have addressed the question whether inter-population differences in otolith traits are genetically encoded or the result of differences in certain habitat parameters (Torres et al. 2000, Stransky et al. 2008, Lombarte et al. 2010, Vignon and Morat 2010).

Mitochondrial DNA is a useful tool in population studies for various reasons, including maternal transmission, limited length and elevated evolution rate (Brown et al. 1979, Wilson et al. 1985). The mitochondrial control region (D-loop, Brown 1983) has been found to be an excellent population marker and has thus been used frequently in the analysis of phylogeography in marine fishes (e.g. Bernardi 2000, Stepien et al. 2001, Astolfi et al. 2005). In addition, many studies have used ribosomal RNA genes because of their highly repetitive nature, ease of manipulation and biological importance in order to elucidate the evolutionary and demographic history of populations (e.g. Sollner-Webb and Mougey 1991, Ghigliotti et al. 2008, Torres-Machorro et al. 2010).

Here we study whether inter-population differences in otolith morphology of a tooth-carp species (Teleostei: Cyprinodontidae) are consistent with data obtained from mitochondrial markers. Aphanius fasciatus (Valenciennes, in Humboldt and Valenciennes 1821) is used as a model because tooth-carps and killifishes are particularly suitable for the study of microevolutionary processes (Villwock 1994, Fuller 2008, Martin and Wainwright 2011). A. fasciatus is widely distributed in coastal and brackish-water habitats of the central and eastern Mediterranean Sea (Wildekamp 1993). A specific attribute of A. fasciatus is that it has no economic use, so the populations are not manipulated but rather reflect the natural distribution of the genotype (Maltagliati 1999). A. fasciatus therefore serves as model organism in many studies on genetic structures and levels of differentiation based on different methods, i.e. osteological characters (Tigano et al. 1999, 2001, Ferrito et al. 2003, 2007), genetic data (Hrbek and Meyer 2003, Triantafyllidis et al. 2007,
Pappalardo et al. 2008), both osteological and genetic data (Maltagliati et al. 2003, Tigano et al. 2004, 2006), and otoliths (Reichenbacher et al. 2007). These studies have revealed that $A$. fasciatus from Italy, Greece and Northern Tunisia is genetically structured by geographic isolation and that a clear link exists between genetic structures and the Pleistocene history of the Mediterranean Sea. Based on this, we hypothesize that genetic structuring is present and recognizable in mitochondrial markers in A. fasciatus from SE Tunisia (of which genetic differentiation has not previously been studied) and, given that otolith morphology is genetically encoded, is also recognizable in differences in otolith morphology. We tested this hypothesis based on three natural $A$. fasciatus populations using otolith morphometry, D-loop and 16S rRNA genes to assess levels of divergence and compare the degree of genetic variability.

\section{MATERIALS AND METHODS}

\section{Sampling and sites}

Adult individuals, identifiable by the typical pigmentation, with standard lengths (SL) ranging from 25 to $43 \mathrm{~mm}$ were collected by hand nets from the coastal sites Sfax and Luza in the Gulf of Gabes and the brackish site Hamdoun on the Dkhila coast (fed by the freshwater source Oued Hamdoun) (Fig. 1, Table 1). Female and male individuals were manually sorted by their distinctive colour pattern and pigmentation and preserved in $99.9 \%$ ethanol. The relatively high number of specimens for the otolith

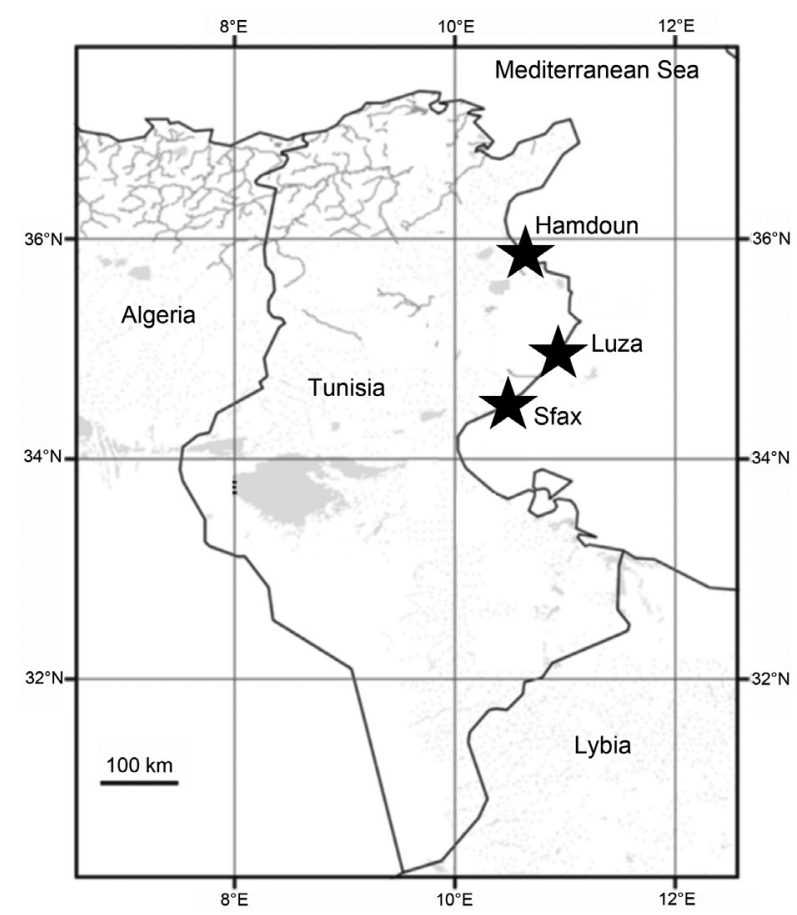

FIG. 1. - Geographic overview of the study sites. 
TABLE 1. - Details of the sites and samples. SL, standard length.

\begin{tabular}{|c|c|c|}
\hline Studied sites & Environmental parameters (June 2010) & Aphanius fasciatus specimens \\
\hline $\begin{array}{l}\text { Sfax, Gulf of Gabes } \\
\left(34^{\circ} 38^{\prime} 08^{\prime}, 16 \mathrm{~N}, 10^{\circ} 39^{\prime} 08^{\prime}, 64 \mathrm{E}\right)\end{array}$ & $\begin{array}{l}\text { Marine, coastal, } \\
\text { water temperature } 23^{\circ} \mathrm{C}, \mathrm{pH} \sim 8.0, \mathrm{O}_{2} \sim 8.4 \text {, } \\
\text { conductivity }(\mathrm{mS} / \mathrm{cm}) 60.7 \text {; } \\
\text { strongly polluted (Messaoudi et al. } 2009 \text { ) }\end{array}$ & $\begin{array}{l}\text { For otolith analysis: } 24 \text { females (SL } 37.4 \pm 4.5 \\
\text { mm), } 40 \text { males (SL } 31.6 \pm 3.8 \mathrm{~mm} \text { ); } \\
\text { For molecular analysis: } 5 \text { specimens }\end{array}$ \\
\hline $\begin{array}{l}\text { Luza, Gulf of Gabes } \\
\left(35^{\circ} 02^{\prime} 63^{\prime}, 0 \mathrm{~N}, 11^{\circ} 01^{\prime} 35^{\prime}, 06 \mathrm{E}\right)\end{array}$ & $\begin{array}{l}\text { Marine, coastal, } \\
\text { water temperature } 24^{\circ} \mathrm{C}, \mathrm{pH} \sim 8.0, \mathrm{O}_{2} \sim 8.4 \text {, } \\
\text { conductivity }(\mathrm{mS} / \mathrm{cm}) 63.7 ; \\
\text { not polluted (Messaoudi et al. 2009) }\end{array}$ & $\begin{array}{l}\text { For otolith analysis: } 23 \text { females (SL } 36.3 \pm 3.3 \\
\text { mm), } 32 \text { males (SL } 31.3 \pm 4.0 \mathrm{~mm} \text { ); } \\
\text { For molecular analysis: } 5 \text { specimens }\end{array}$ \\
\hline $\begin{array}{l}\text { Hamdoun, Dkhila coast } \\
\left(35^{\circ} 47^{\prime} 20^{\prime}, 02 \mathrm{~N}, 10^{\circ} 41^{\prime} 00^{\prime}, 09 \mathrm{E}\right)\end{array}$ & $\begin{array}{l}\text { Brackish, coastal, freshwater influx, } \\
\text { water temperature } 29^{\circ} \mathrm{C}, \mathrm{pH} \sim 8.0, \mathrm{O}_{2} \sim 8.4 \text {, } \\
\text { conductivity }(\mathrm{mS} / \mathrm{cm}) 56.3 \text {; } \\
\text { polluted (Afli } \text { et al. } 2008 \text { ) }\end{array}$ & $\begin{array}{l}\text { For otolith analysis: } 30 \text { females (SL } 33.6 \pm 3.5 \\
\text { mm), } 31 \text { males (SL } 30.7 \pm 5.0 \mathrm{~mm} \text { ); } \\
\text { For molecular analysis: } 6 \text { specimens }\end{array}$ \\
\hline
\end{tabular}

study is due to the fact that we had to check whether sex dimorphism is reflected in otolith morphology as well, and that artefacts due to restricted sample sizes had to be avoided. Dissected otoliths are deposited in the Bavarian State Collection for Palaeontology and Geology in Munich, Germany (accession number BSPG 2009 X).

\section{Samples for comparison}

Aphanius fasciatus from Corsica (Fanjo Delta), comprising 16 females (SL 29.5 $\pm 3.3 \mathrm{~mm}$ ) and two males $(28.7 \pm 1.1 \mathrm{~mm})$, was used for comparison of the otoliths (accession number BSPG 2004 II). This sample has also been used in Reichenbacher et al. (2007). Phylogenetic analyses included sequences of two outgroup species, A. iberus and A. chantrei. GenBank reference numbers are EF640857 for 16S rDNA (A. iberus) and U06062 for D-loop (A. chantrei), respectively.

\section{Otolith preparation and analyses}

Otolith dissection and preparation followed standard procedures. Study of otolith morphology was based on SEM images (LEO 1430 VP at the Zoological State Collection Munich); otolith terminology follows Nolf (1985) and Tuset et al. (2008) (Fig. 2A). For morphometric analyses, digital images were captured using a Leica DFC 295 camera and the Leica Image Access Software (IMAGIC 1000, Imagic Bildverarbeitung AG, Glattbrugg, Switzerland). Three angles and eight linear distances were measured (Fig. 2B) and ten otolith variables were calculated from the measurements; they describe specific segments of the otolith (Table 2A; for details see Reichenbacher et al. 2007).

Statistical analyses were carried out using SPSS version 19.0.0 (IBM SPSS Inc, 2011). The t-test was applied to test whether the studied otoliths were influenced by sex dimorphism. One-way ANOVA with

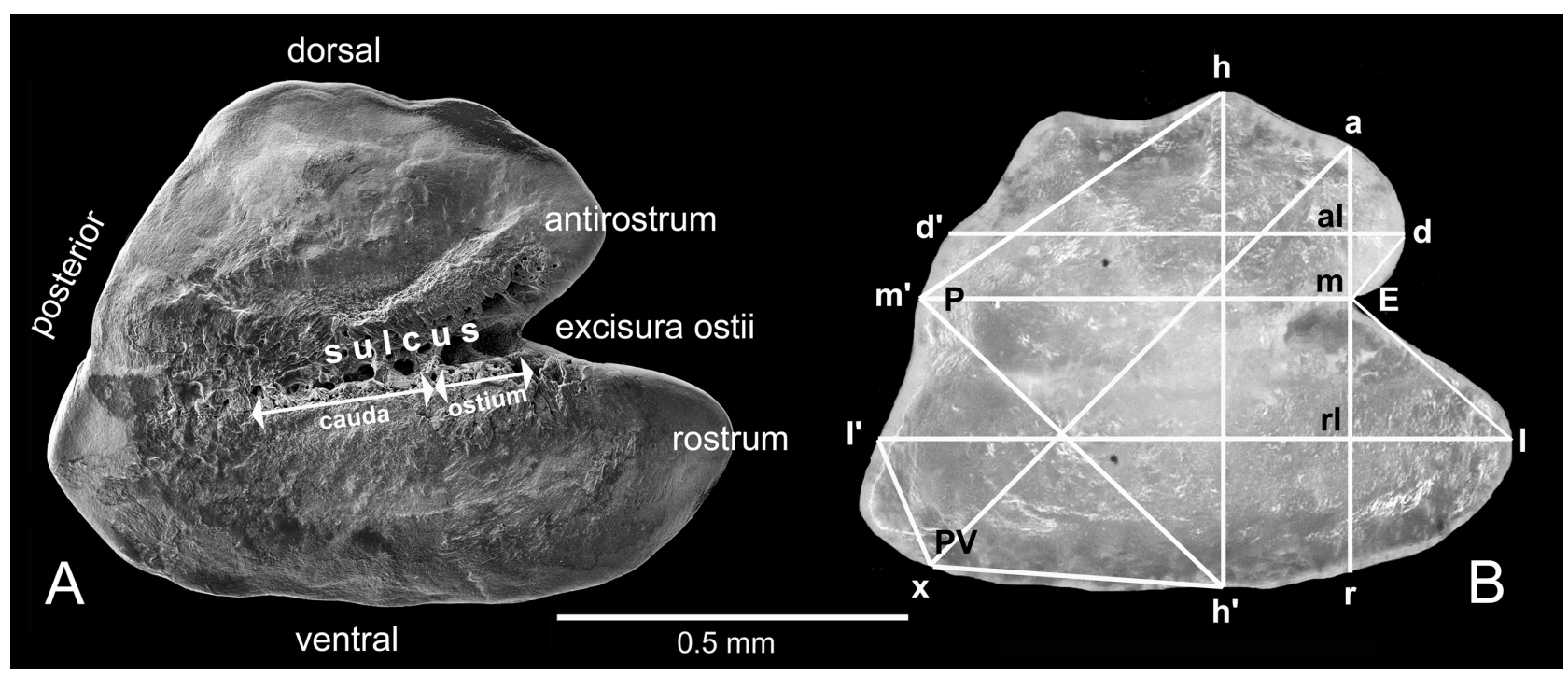

FIG. 2. - Otolith morphology of Aphanius fasciatus from Luza, SE Tunisia (BSPG 2009 X 78) (A) and linear measurements and angles used for otolith morphometry (after Reichenbacher et al. 2007) (B); otoliths are shown in medial view; terminology of otolith characters follows Nolf (1985) and Tuset et al. (2008). 1-1', length; h-h', height; m-a, antirostrum height; m-r, rostrum height; rl-l, rostrum length; al-d, antirostrum length; $\mathrm{m}-\mathrm{m}^{\prime}$, medial length; $\mathrm{d}-\mathrm{d}^{\prime}$, dorsal length; E, excisura angle; $\mathrm{P}$, posterior angle; $\mathrm{PV}$, posteroventral angle. 
Duncan's post hoc test $(\mathrm{p}<0.001)$ was used to determine which of the otolith variables significantly differed between the populations. Canonical discriminant analysis was performed for a multivariate analysis of the otolith variables; classification success was tested with jackknifed cross-validation. An otolith-based dendrogram was created based on the Euclidean distance as a measure of dissimilarity and the "between groups linkage method" as the clustering algorithm.

\section{Molecular analysis}

The molecular study included mitochondrial DNA D-loop (D-loop) and 16S ribosomal RNA (16S rRNA) analyses. Total DNA was extracted from muscle tissue preserved in ethanol, using a Wizard Genomic DNA extraction kit following the manufacturer's protocol (Promega). The concentration of extracted DNA was spectrophotometrically estimated.

For the D-loop analysis, a $378 \mathrm{bp}$ fragment of the mitochondrial control region was amplified from total DNA extracts using newly designed primers: AFDF: 5'-CCCCGCCGCCC ATCAATAAT-3' and AFDR: 5'- CCAGGAATAATTCACTAAGTGC-3'. D -loop sequence of Aphanius fasciatus (GenBank accession AM884570) was used to make the alignment that allowed the definition of these primers.

For the 16S rRNA gene analysis, a fragment of 154 bp was amplified from total DNA extracts using also newly designed primers: AFrF 5'- GTA ATC CAG GTC AGT TTC TAT CT-3' and AFrR 5'- GTA ATC CAG GTC AGT TTC TAT CT-3'. The primers were designed on the basis of the 16S ribosomal RNA sequence of Aphanius fasciatus (GenBank accession EF640854).

Polymerase chain reaction (PCR) amplification was performed on total genomic DNA in a total volume of $50 \mu \mathrm{l}$ containing: 20ng DNA, $2.5 \mathrm{mM}$ dNTPs, Taq Buffer (1X), 50mM $\mathrm{MgCl}_{2}, 25$ pmol from each primer and $0.5 \mathrm{U}$ of Taq DNA polymerase (Madison, Promega). The final volume $(50 \mu \mathrm{l})$ was adjusted by adding sterile distilled water. Negative controls were performed for all reactions.

The cycling profile was $94^{\circ} \mathrm{C}$ for $3 \mathrm{~min}$, followed by 35 cycles at $94^{\circ} \mathrm{C}$ for $1 \mathrm{~min}, 56^{\circ} \mathrm{C}$ for $1 \mathrm{~min}, 72^{\circ} \mathrm{C}$ for $1 \mathrm{~min}$, and a final 10 -min extension step at $72^{\circ} \mathrm{C}$.

The amplified DNA segments encoding D-loop and 16S rRNA genes were purified using the "Wizard PCR preps DNA purification kit" according to the manufacturer's instructions (Promega, Madison, WI) and then sequenced. Cycle sequencing was performed by Macrogen Inc. using Automated Applied Biosystems (AB) sequencing and the Taq Dye Deoxy Terminator cycle sequencing kit. Chromatograms and alignments were visually checked and verified.

\section{Phylogenetic analysis}

Sequence alignments were inspected using the BioEdit Sequence Alignment Editor (v. 7.0.5.2, Hall
1999). No indels or codon stops were found in the dataset.

JModelTest (Posada 2008) was run to determine the most suitable model of DNA evolution to consider for our set of sequences through the five model selection strategies available in the program. neighbour-joining and maximum likelihood analyses were performed using SEAVIEW (Gouy et al. 2010), and PHYML on line at the ATGC Montpellier bioinformatics platform (v3.0, Guindon and Gascuel 2003), respectively. The evolutionary relationships among sequences were also estimated with the Bayesian Markov chain Monte Carlo (MCMC) phylogenetic analyses (BI) as included in MrBayes v3.1 using the default priors (Huelsenbeck and Ronquist 2001, Ronquist and Huelsenbeck 2003). Three heated chains and a single cold chain were employed in all MCMC analyses, and runs were initiated with random trees. Two independent MCMC runs were conducted with 2 million generations per run, and trees and parameters were sampled every 100 generations. Stationarity was assessed by examining the average standard deviation of split frequencies and the potential scale reduction factor (Ronquist et al. 2005). For each run, the first $25 \%$ of sampled trees were discarded as burn-in. Bayesian posterior probabilities were used to assess branch support of the MCMC tree.

The genetic variation within groups was then estimated using basic statistics. Haplotype (h) and nucleotide ( $\varpi$ in percentage) diversities and their standard deviations $( \pm \mathrm{SD})$ were estimated using DNASP (v4.10.9, Rozas et al. 2003). The MEGA software version 3.1 (Kumar et al. 2004) was used to estimate genetic distances (Tamura and Nei 1993).

Finally, $F_{\mathrm{ST}}$ values were calculated and we used analysis of molecular variance (AMOVA), as implemented in ARLEQUIN (version 3, Excoffier et al. 2005) to quantify the genetic variation among groups, among populations within groups, and within populations. The variance components of the different hierarchical levels were tested statistically by nonparametric randomization tests using 10000 permutations.

Monophyly of trees was tested by creating a monophyletic backbone tree for each of the clades. The backbone tree was then used as a constraint tree for a maximum likelihood search using the parameters from the unconstrained maximum likelihood tree. The monophyletic signal was tested with the ShimodairaHasegawa test (Shimodaira and Hasegawa, 1999) using PAUP* v4.0b10 (Swofford 2003), with RELL (Kishino et al. 1990) (resampling estimated log-likelihood) optimization and 10000 bootstrap replicates.

\section{RESULTS}

\section{Results of otolith analysis}

All studied A. fasciatus otoliths are characterized by a triangular to slightly rounded contour (Fig. 3). The rostrum is present and has a rounded or slightly 


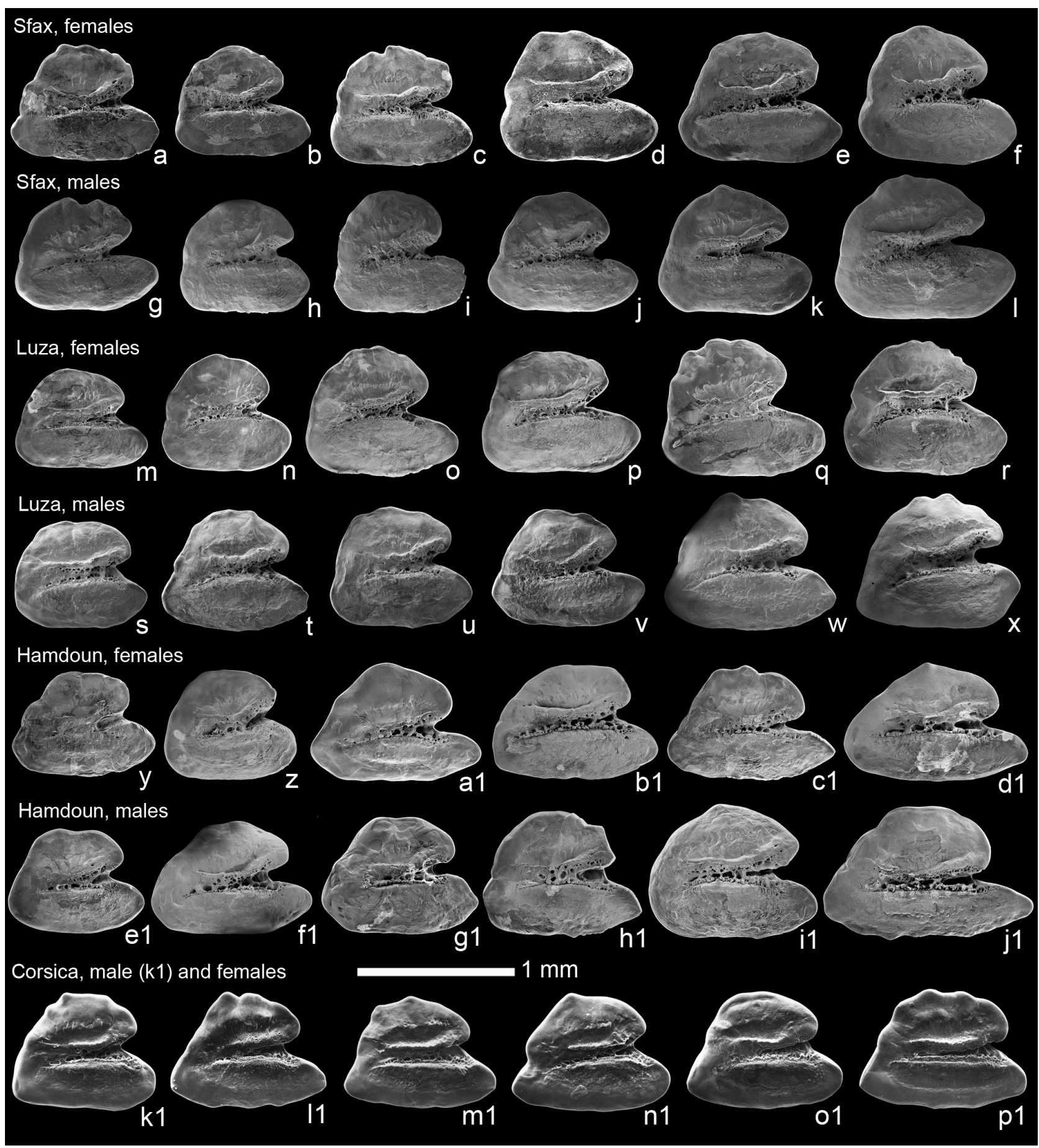

FIG. 3. - Otoliths of individuals of Aphanius fasciatus from the study sites. All images are SEM micrographs, showing left otoliths in medial view, except i1, which is a mirrored right otolith. Collection numbers and standard lengths of specimens (in brackets, in mm): a-f, BSPG 2009 X 23 (31.5), -21 (33.0), -15 (38.0), -8 (36.0), -20 (39.0), -18 (42.0); g-1, BSPG 2009 X 40 (31.0), -35 (33.0), -52 (35.0), -53 (37.0), -48 (41.0), -55 (42.0); m-r, BSPG 2009 X 105 (31.0), -100 (33.0), -121 (37.0), -120 (38.0), -112 (41.5), -98 (44.0), s-x, BSPG 2009 X 64 (29.0), -76 (33.0), -87 (34.0), -78 (38.0), -88 (39.5), -95 (40.0); y-d1, BSPG 2009 X 175 (31.5), -178 (33.0), -181 (35.0), -155 (37.5), -168 (39.5), - 152 (41.0); e1-j1, BSPG 2009 X 187 (32.0), -131 (33.0), 124 (35.5), 141 (38.0), -148 (41.5), -125 (43.5); k1-p1, BSPG 2004 II 147 (32.0), -148 (33.0), -154 (33.0), -151 (34.0), -144 (38.0), -145 (39.0).

pointed tip. The antirostrum is shorter than the rostrum and rounded, the excisura ostii is wide with a deep, acute notch. The sulcus is located in a median position and subdivided into a small, slightly deep- ened, funnel-like shaped ostium and a long, straight or posteriorly slightly bent cauda covered with colliculi. The inner face of all otoliths is planar, the outer face slightly convex. 
TABLE 2. - Values of otolith variables (mean values and standard deviations) in the studied Aphanius fasciatus populations (A) and list of otolith variables that differ significantly between the studied populations (one-way ANOVA with Duncan post hoc test, $\mathrm{p}<0.001)(\mathrm{B})$; $n$, number of specimens.

\begin{tabular}{|c|c|c|c|c|}
\hline A & Sfax $(n=55)$ & Luza $(n=64)$ & Hamdoun $(n=61)$ & Corsica $(n=18)$ \\
\hline Length-height-index & $1.22( \pm 0.06)$ & $1.23( \pm 0.09)$ & $1.27( \pm 0.11)$ & $1.30( \pm 0.05)$ \\
\hline Relative antirostrum height & $36.3( \pm 4.1)$ & $35.7( \pm 3.0)$ & $34.4( \pm 3.7)$ & $32.4( \pm 3.2)$ \\
\hline Relative rostrum height & $52.5( \pm 2.7)$ & $52.6( \pm 2.2)$ & $52.4( \pm 3.6)$ & $54.1( \pm 2.7)$ \\
\hline Relative rostrum length & $28.9( \pm 3.5)$ & $28.2( \pm 3.4)$ & $24.4( \pm 3.2)$ & $25.2( \pm 3.5)$ \\
\hline Relative antirostrum length & $15.8( \pm 3.5)$ & $14.6( \pm 3.7)$ & $11.8( \pm 3.5)$ & $13.1( \pm 2.9)$ \\
\hline Relative medial length & $67.3( \pm 4.0)$ & $68.0( \pm 3.8)$ & $71.5( \pm 4.2)$ & $68.1( \pm 3.5)$ \\
\hline Excisura angle & $89.7( \pm 10.6)$ & $92.6( \pm 11.9)$ & $102.1( \pm 14.1)$ & $93.1( \pm 8.9)$ \\
\hline Posterior angle & $95.7( \pm 8.3)$ & $95.0( \pm 9.8)$ & $92.3( \pm 11.7)$ & $86.1( \pm 12.5)$ \\
\hline Relative dorsal length & $73.2( \pm 3.9)$ & $72.8( \pm 3.0)$ & $71.8( \pm 4.8)$ & $70.6( \pm 3.0)$ \\
\hline Posteroventral angle & $127.9( \pm 9.3)$ & $128.3( \pm 8.6)$ & $136.4( \pm 7.8)$ & $128.2( \pm 22.0)$ \\
\hline
\end{tabular}

B

Sfax vs. Luza

Sfax/Luza vs. Hamdoun

Sfax/Luza vs. Corsica

Hamdoun vs. Corsica

Rel. rostrum length, rel. antirostrum length, rel. medial length

Length-height-index, rel. antirostrum height, rel. rostrum length, posterior angle Rel. medial length

\section{Within-population differences}

Based on qualitative comparison of otolith images (Fig. 3) and evaluation of standard deviations of otolith variables (Table 1A), the variation of the otolith morphology within a population is low for both the Sfax (Fig. 3a-1) and Corsica (Fig. 3k1-p1) fishes. Within the Luza population (Fig. 3m-x), a few otoliths possess a rounded rather than triangular contour (Fig. 3s) or an unusually short rostrum (Fig. 3x), so the variation within the Luza population is considered as low to moderate. In contrast, distinctive intra-population differences are visible in the otoliths from the Hamdoun fishes (Fig. 3y-j1). These otoliths include a "normal" otolith type (Fig. 3y-z, e1, g1-i1) similar to that seen in Sfax, Luza and Corsica individuals, and a second, more elongate, narrow-triangular type (Fig. 3b1-d1, j1); intermediate morphologies are also present (Fig. 3a1, f1). The relatively high standard deviations of some otoliths variables, i.e. $\mathrm{L} / \mathrm{H}$ index, relative rostrum height, excisura angle, and relative dorsal length (Table 2A), corroborate these observations for the Hamdoun fishes.

\section{Inter-population differences}

Based on qualitative comparison of otolith images (Fig. 3) and uni- and multivariate statistics (Table 2), no clear differences in otolith morphology and otolith variables can be recognized between the populations from Sfax and Luza. In contrast, three otolith variables are significantly different between Sfax/Luza and Hamdoun, and four otoliths variables are significantly different between Sfax/Luza and Corsica. Moreover, a single otolith variable is different between the individuals from Hamdoun and Corsica (Table 2B). The great similarity between the Sfax and Luza otoliths, but their clear differentiation from the Hamdoun and Corsica otoliths, is additionally shown by a dendrogram using the Euclidean distance as a measure of dissimilarity and the

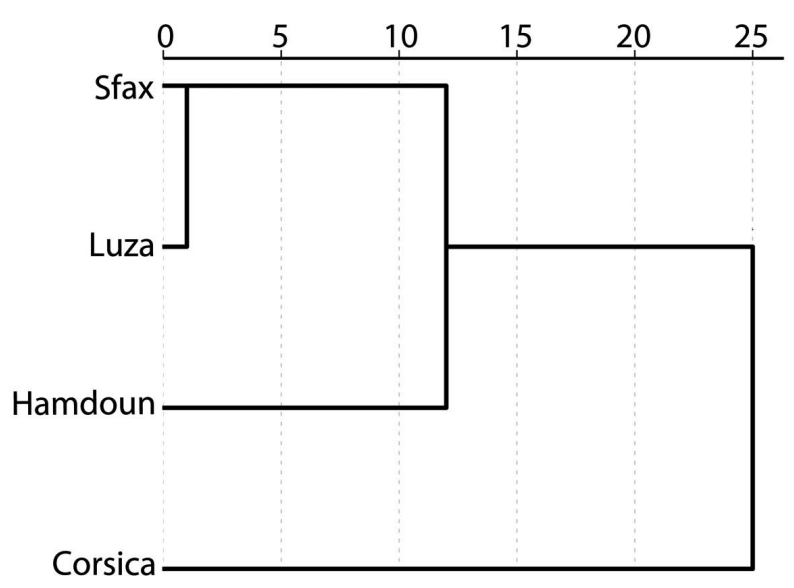

FIG. 4. - Relationships between Aphanius fasciatus populations as suggested by cluster analysis based on otolith variables (Euclidean distances of mean values \pm standard deviations).

TABLE 3. - Classification matrix of the CDA (jackknifed) based on the otolith variables of the studied Aphanius fasciatus populations. The otoliths from Sfax and Luza were merged.

\begin{tabular}{lccc}
\hline & \multicolumn{3}{c}{ Predicted classification } \\
& Sfax/Luza & Hamdoun & Corsica \\
\hline Sfax/Luza $(n=119)$ & $\mathbf{7 3 . 1}(\mathbf{8 7})$ & $16.0(19)$ & $10.9(14)$ \\
Hamdoun $(n=61)$ & $14.8(9)$ & $\mathbf{7 2 . 1}(\mathbf{4 4 )}$ & $13.1(8)$ \\
Corsica $(n=18)$ & $11.1(2)$ & $16.7(3)$ & $\mathbf{7 2 . 2 ( 1 3 )}$ \\
\hline
\end{tabular}

The percentages in rows represent the classification into the populations given in columns (correct classifications are highlighted in bold), corresponding numbers of individuals are given in brackets. Function 1 captures $73.9 \%$ of the variation and function 2 captures $26.1 \%$ of the variation. Overall classification success is $72.7 \%$ (Wilks' $\lambda=0.78, \mathrm{p}<0.001)$. $n$, number of specimens.

"between groups linkage method" as the clustering algorithm (Fig. 4). Moreover, the canonical discriminant analysis reveals a high classification success for each group (Sfax/Luza, Hamdoun, Corsica) and thus clearly supports the importance of otolith variables for deciphering inter-population differences (Table 3). 

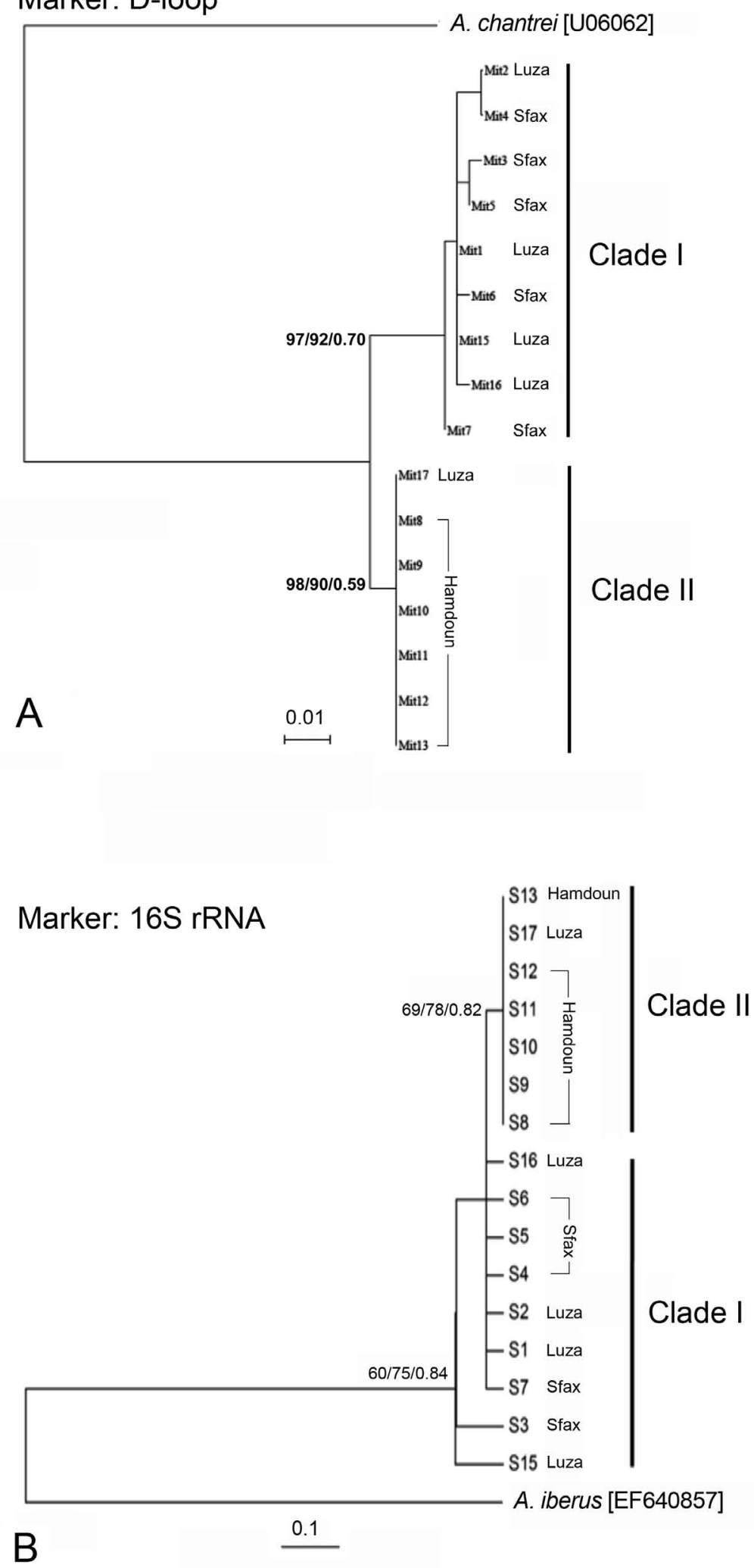

FIG. 5. - Maximum likelihood phylogenetic relationships for 16 specimens of Aphanius fasciatus from Sfax, Luza and Hamdoun (SE Tunisia) based on D-loop sequences (A) and 16S RNA sequences (B). Numbers beside nodes indicate bootstrap values $(\%>50)$ obtained by the neighbour-joining, maximum likelihood and posterior probabilities for Bayesian analysis, respectively. 


\section{Results of molecular analysis}

A total of 16 sequences of $378 \mathrm{bp}$ was obtained for the D-loop of A. fasciatus (Genbank accession numbers: JX406312 to JX406327). Among them, eight different haplotypes were identified. Fourteen sites were variable and 11 were parsimony-informative. The TPM1uf model with a gamma distribution shape parameter equal to 0.016 and the proportion of invariable sites equal to 0.169 was the best evolutionary model. The nucleotides frequencies were $37.01 \%, 17.38 \%, 15.79 \%$ and $29.82 \%$ for $\mathrm{A}, \mathrm{C}, \mathrm{G}$ and $\mathrm{T}$, respectively. The different phylogenetic analyses provided very similar topologies and for the sake of simplicity we only present the phylogenetic tree corresponding to the maximum likelihood analysis (Fig. 5A). The A. fasciatus sequences were distributed among two clades that are separated by a moderate value of Tamura and Nei genetic divergence $(2.7 \pm 0.08 \%)$. Clade I consists of the Sfax and Luza specimens, while clade II comprises the Hamdoun specimens. Genetic diversity in clade II (Nucleotide diversity $\mathrm{Pi}=0.00 \pm 0.000$; Haplotype diversity $\mathrm{Hd}=0.99 \pm 0.000$ ) is slightly higher than in clade I $(\mathrm{Pi}=0.0005 \pm 0.000 ; \mathrm{Hd}=0.94 \pm 0.070)$. The mean $\mathrm{F}_{\mathrm{ST}}$ value between clades I and II is $0.88(\mathrm{p}=0.001)$. Most of the variation is explained between the two clades $(89.7 \%)$, whereas variation within clades is smaller (11.75\%) (Fig. 5A).

A total of 16 sequences of $154 \mathrm{bp}$ was obtained for the 16S rRNA of A. fasciatus (pending submission to treebase). Among them, four different haplotypes were identified. Fifteen sites were variable and two were parsimony informative. The F81 model with a gamma distribution shape parameter equal to 0.016 and the proportion of invariable sites equal to 0.00 was the best evolutionary model. The nucleotides frequencies were $31.9 \%, 27.47 \%, 19.7 \%$ and $20.93 \%$ for A, C, G and T, respectively. The different phylogenetic analyses resulted in very similar topologies and for the sake of simplicity we only represent the phylogenetic tree corresponding to the maximum likelihood analysis (Fig. 5B). The A. fasciatus sequences were distributed among two clades, of which clade I includes the Sfax and Luza specimens, and clade II comprises the Hamdoun specimens. The clades are separated by a moderate value of Tamura and Nei genetic divergence $(0.7 \pm 0.007 \%)$, and genetic diversity in clade $\mathrm{I}(\mathrm{Pi}=0.0029 \pm 0.001$; $\mathrm{Hd}=0.417 \pm 0.191)$ is slightly higher than in clade II $(\mathrm{Pi}=0.002 \pm 0.000 ; \mathrm{Hd}=0.286 \pm 0.019)$. The mean $\mathrm{F}_{\mathrm{ST}}$ value between clades I and II is $0.79(\mathrm{p}=0.001)$. Most of the variation is explained among the two clades $(80.07 \%)$, whereas variation within the clades is smaller $(20.72 \%)$.

For both mitochondrial markers (D-loop and $16 \mathrm{Sr}-$ RNA), Shimodaira-Hasegawa tests based on the maximum likelihood tree indicate that clade II (Hamdoun) represents a monophyletic clade $(\mathrm{P}<0.05)$.

\section{DISCUSSION}

Fish populations inhabiting similar environments and interconnected through migration and gene flow usually display largely similar phenotypic and genetic traits (e.g. Carvalho 1993). Aphanius fasciatus is widely distributed along the southeastern coast of Tunisia. Hence, gene flow, resulting in mixing between populations and stabilization of the basic genome, can be expected regardless of whether the species is known for having a rather sedentary life history, with large demersal eggs and without larval dispersal stages (Maltagliati 1999). However, both otolith and mitochondrial marker analyses (D-loop, 16S rRNA) are indicative of restricted gene flow between the A. fasciatus individuals from Sfax/ Luza and Hamdoun. Moreover, the dendrogram and trees reveal congruent topologies (Figs 4-5). In the 16S rRNA-based tree, the monophyly of clade II (Hamdoun) is slightly less well supported, which might be due to the reduced substitution rate in $16 \mathrm{~S}$ in comparison with the mitochondrial control region (D-loop). Another line of evidence in support of a genetic basis for population differences in otolith morphology is the absence of otolith differences between the A. fasciatus individuals from the heavily polluted site Sfax (Messaoudi et al. 2009) and the non-polluted site Luza.

These results raise the question as to what caused the genetic divergence between the A. fasciatus populations from SE Tunisia? The occurrence of genetic divergence within a species is affected by many factors, including population size, time since isolation, and porosity of the isolating barrier or mechanism (Frankham 1995). Genetic drift is faster if populations are small or the isolating barrier is very effective (Leis et al. 2011). A factor that significantly influenced the physical connection between coastal sites in the Mediterranean Sea was the changing global sea level between glacial and interglacial climate conditions during the Pleistocene (1,8 million to 11000 years ago) (Lambeck et al. 2002). Genetic differentiation among populations that may be linked with Pleistocene sea level falls are known for several teleost species from the Mediterranean Sea, including the silverside Atherina boyeri Risso, 1810 (Milana et al. 2012 and references therein) and the goby Pomatoschistus tortonesei (Mejri et al. 2009). According to these studies, distinctive oceanic currents in the Mediterranean Sea represent hydrographic barriers for coastal species and maintained their differentiation for long periods of time. In the case of A. fasciatus, the strong sea level drop (up to $-120 \mathrm{~m}$ ) during the last Pleistocene glaciation (20000 years ago) was suggested to be responsible for the genetic divergence between populations from Italy (Rocco et al. 2007). Moreover, the sea level fall during the Early Pleistocene ( $c a .1 .7$ million years ago) was favoured as an explanation for the genetic divergence between $A$. fasciatus populations from Sicily, northern Tunisia and Malta (Tigano et al. 2006). 
We therefore hypothesize that the sea level fall during the Early or Late Pleistocene and the current oceanographic conditions have affected the genetic structure of A. fasciatus from SE Tunisia. Notably, the allopatric divergence that developed during times of isolation was strong enough to prevent gene flow during the subsequent sea level rise when the climate became warm and wet again. As mentioned above, the Hamdoun site (inhabited by clade II) is fed by freshwater, whereas the sites of Sfax and Luza (inhabited by clade I) are strictly coastal. We therefore suggest that the specific salinity and hydrological parameters of the Hamdoun site have triggered the genetic divergence in this population. This assumption concurs with results from previous studies, in which specific salinity parameters have been detected as the causative agents of strong selective pressure on organisms that eventually led to reproductive isolation in spite of possible intermingling during larval and adult life stages (Bekkevold et al. 2005, Fuller 2008, Williams et al. 2008).

If our assumption that inter-population differences in otolith morphology are genetically encoded is correct, then the results of our study also indicate genetic divergence between A. fasciatus from Corsica (Fanjo Delta) and SE Tunisia (Sfax/Luza). A likely explanation for this pattern is that the respective populations are separated by the oceanic currents of the Sicily Strait (Astraldi et al. 1999, 2002, Béranger et al. 2005), which is known to represent a breakpoint to gene flow in the Mediterranean basin (Mejri et al. 2009). On the other hand, the otolith similarities between $A$. fasciatus from Corsica and the northernmost of the here studied SE-Tunisian sites, i.e. Hamdoun, are difficult to explain without conducting additional molecular studies as the Strait of Sicily probably prevented gene flow also between these sites. Also the development of new markers (e.g. nuclear genome) would be useful in order to elucidate in detail the micro-evolutionary processes acting in Aphanius fasciatus populations.

The results of this study shed new light on previous work on the differences in otolith morphology between populations of Aphanius iberus (Reichenbacher and Sienknecht 2001) and A. dispar (Reichenbacher et al. 2009a, 2009b, Teimori et al. 2012a, 2012b). In these studies, otolith differences have been interpreted as indicating allopatric genetic divergence, but a test of this interpretation by molecular data analyses has not been conducted. We assume that a genetic basis in otolith morphology is indicative for population differences also in A. iberus and A. dispar and probably also in several other species of Aphanius. Our study therefore may also serve as a starting point for the development of a new utility of otolith morphology for analysing genetic structures between populations of Aphanius species and also between other species of teleost fishes. Such analyses are important for ecosystem management and conservation of genetic diversity (e.g. Clarke et al. 2011, Leis et al. 2011). In addition, this new importance of otoliths can provide an innovative approach for studying evolution and phylogeography of fossil teleost fish faunas, which are often preserved solely based on otoliths.

\section{ACKNOWLEDGEMENTS}

We thank D. Erpenbeck (GeoBioCenter, Munich), M. Krings (LMU Munich), A. Ben Faleh (Monastir) and two anonymous reviewers for helpful comments that improved the quality of this paper. We also thank R. Melzer (Bavarian State Collection of Zoology, Munich) for providing access to the SEM.

\section{REFERENCES}

Afli A., Ayari R., Zaabi S. 2008. Ecological quality of some Tunisian coast and lagoon locations, by using benthic community parameters and biotic indices. Estuar. Coast. Shelf. Sci. 80: 269-280.

Astolfi L., Dupanloup I., Rossi R., Bisol P.M., Faure E., Congiu L. 2005. Mitochondrial variability of sand smelt Atherina boyeri populations from north Mediterranean coastal lagoons. Mar. Ecol. Prog. Ser. 297: 233-243.

Astraldi M., Gasparini G.P., Vetrano A., Vignudelli S. 2002. Hydrographic characteristics and interannual variability of water masses in the central Mediterranean: a sensitivity test for long-term changes in the Mediterranean Sea. Deep-Sea Res. I 49: 661-680.

Astraldi M., Balopoulos S., Candela J., Font J., Gacic M., Gasparini G.P., Manca B., Theocharis A., Tintoré J. 1999. The role of straits and channels in understanding the characteristics of Mediterranean circulation. Progr. Oceanogr. 44: 65-108.

Bekkevold D., André C., Dahlgren T.G., Clausen L.A., Torstensen E., Mosegaard H., Carvalho G.R., Christensen T.B., Norlinder E., Ruzzante D.E. 2005. Environmental correlates of population differentiation in Atlantic herring. Evolution 59: 2656-2668.

Béranger K., Mortier L., Crépon M. 2005. Seasonal variability of water transport through the Straits of Gibraltar, Sicily and Corsica, derived from a high-resolution model of the Mediterranean circulation. Progr. Oceanogr. 66: 341-364.

Bernardi G. 2000. Barriers to gene flow in Embiotoca jacksoni, a marine fish lacking a pelagic larval stage. Evolution 54: 226-237.

Brown W.M. 1983. Evolution of animal mitochondrial DNAs. In: Nei M., Koehn R.K. (eds), Evolution of Genes Proteins. Sinauer, Sunderland, MA. pp. 62-88.

Brown W.M., George M., Wilson A.C. 1979. Rapid evolution of animal mitochondrial DNA. Proc. Natl. Acad. Sci. USA 76: 1967-1971.

Campana S. 1999. Chemistry and composition of fish otoliths: pathways, mechanisms and applications. Mar. Ecol. Prog. Ser. 188: 263-297.

Carvalho G.R. 1993. Evolutionary aspects of fish distribution: genetic variability and adaptation. J. Fish Biol. 43: 53-73.

Castonguay M., Simard P., Gagnon P. 1991. Usefulness of Fourier analysis of otolith shape for Atlantic mackerel (Scomber scombrus) stock discrimination. Can. J. Fish. Aquat. Sci. 48: 296-302.

Clarke L.M., Thorrold S.R., Conover D.O. 2011. Population differences in otolith chemistry have a genetic basis in Menidia menidia. Can. J. Fish. Aquat. Sci. 68: 105-114.

Excoffier L., Laval G., Schneider S. 2005. Arlequin ver. 3.0: An integrated software package for population genetics data analysis. Evol. Bioinform. Online 1: 47-50.

Ferrito V., Maltagliati F., Mauceri A., Adorno A., Tigano C. 2003. Morphological and genetic variation in four Italian populations of Aphanius fasciatus (Teleostei, Cyprinodontidae). It. J. Zool. 70: 115-121.

Ferrito V., Mannino M.C., Pappalardo A.M., Tigano C. 2007. Morphological variation among populations of Aphanius fasciatus Nardo, 1827 (Teleostei, Cyprinodontidae) from the Mediterranean. J. Fish Biol. 70: 1-20. 
Frankham R. 1995. Conservation genetics. Annu. Rev. Gen. 29: 305-327.

Fuller R.C. 2008. Genetic incompatibilities in killifish and the role of environment. Evolution 62: 3056-3068.

Ghigliotti L., Mazzei F., Ozouf-Costaz C., Christiansen J.S., Fevolden S.E., Pisano E. 2008. First cytogenetic characterization of the sub-arctic marine fish Mallotus villosus (Müller, 1776), Osmeriformes, Osmeridae. Genet. Mol. Biol. 31: 180-187.

Girone A., Nolf D. 2009. Fish otoliths from the Priabonian (Late Eocene) of North Italy and South-East France - Their paleobiogeographical significance. Rev. Micropal. 52: 195-218.

Gouy M., Guindon S., Gascuel O. 2010. SeaView version 4: A multiplatform graphical user interface for sequence alignment and phylogenetic tree building. Mol. Biol. Evol. 27: 221-224.

Guindon S., Gascuel O. 2003. A simple, fast, and accurate algorithm to estimate large phylogenies by maximum likelihood. Syst. Biol. 52: 696-704.

Hall T.A. 1999. BioEdit: a user-friendly biological sequence alignment editor and analysis program for Windows 95/98/NT. Nucleic Acids Symp. Ser. 41: 95-98.

Hrbek T., Meyer A. 2003. Closing of the Tethys sea and phylogeny of Eurasian killifishes (Cyprinodontiformes: Cyprinodontidae). J. Evol. Biol. 16: 17-36.

Huelsenbeck J. P., Ronquist F. 2001. MRBAYES: Bayesian inference of phylogeny. Bioinform. 17: 754-755.

Humboldt F.H.A., Valenciennes A. 1821. Recherches sur les poissons fluviatiles de l'Amérique Equinoxiale. In: Humboldt F.H.A., de Bonpland A.J.A. (eds), Voyage de Humboldt et Bonpland, Vol. 2. Schoell et Dufour, Paris, p. 160.

Kishino H., Miyata T., Hasegawa M. 1990. Maximum likelihood inference of protein phylogeny and the origin of chloroplasts. $J$. Mol. Evol. 30: 151-160.

Kumar S., Tamura K., Nei M. 2004. MEGA3: integrated software for molecular evolutionary genetics analysis and sequence alignment. Brief Bioinform. 5: 150-163.

Lambeck K., Esat T.M., Potter E.K. 2002. Links between climate and sea levels for the past three million years. Nature 419: 199-206.

Leis J.M., Van Herwerden L., Patterson H.M. 2011. Estimating connectivity in marine fish populations: What works best? Oceanogr. Mar. Biol. Annu. Rev. 49: 193-234.

Lombarte A., Palmer M., Matallanas J., Gómez-Zurita J., MoralesNin B. 2010. Ecomorphological trends and phylogenetic inertia of otolith sagittae in Nototheniidae. Environ. Biol. Fish. 89: 607-618.

Maltagliati F. 1999. Genetic divergence in natural populations of the Mediterranean brackish-water killifish Aphanius fasciatus. Mar. Ecol. Prog. Ser. 179: 155-162.

Maltagliati F., Domenici P., Franch Fosch C., Cossu P., Casu M., Castelli A. 2003. Small-scale morphological and genetic differentiation in the Mediterranean killifish Aphanius fasciatus (Cyprinodontidae) from a coastal brackish-water pond an adjacent pool in northern Sardinia. Oceanol. Acta 26: 111-119.

Martin C.H., Wainwright P.C. 2011. Trophic novelty is linked to exceptional rates of morphological diversification in two adaptive radiations of Cyprinodon pupfish. Evolution 65: 2197-2212.

Mejri R., Brutto S.L., Hassine O.K.B., Arculeo M. 2009. A study on Pomatoschistus tortonesei Miller 1968 (Perciformes, Gobiidae) reveals the Siculo-Tunisian Strait (STS) as a breakpoint to gene flow in the Mediterranean basin. Mol. Phyl. Evol. 53: 596-601.

Mérigot B., Letourneur Y., Lecomte-Finiger R. 2007. Characterization of local populations of the common sole Solea solea (Pisces, Soleidae) in the NW Mediterranean through otolith morphometrics and shape analysis. Mar. Biol. 151: 997-1008.

Messaoudi I., Kessabi K., Kacem A., Said K. 2009. Incidence of spinal deformities in natural populations of Aphanius fasciatus Nardo, 1827 from the Gulf of Gabes, Tunisia. Afr. J. Ecol. 47: 360-366.

Milana V., Franchini P., Sola L., Angiulli E., Rossi A.R. 2012. Genetic structure in lagoons: the effects of habitat discontinuity and low dispersal ability on populations of Atherina boyeri. Mar. Biol. 159: 399-411.

Monteiro L.R., Di Beneditto A.P.M., Guillermo L.H., Rivera L.A. 2005. Allometric changes and shape differentiation of sagitta otoliths in sciaenid fishes. Fish. Res. 74: 288-299.

Nolf D. 1985. Otolithi piscium. Handbook of paleoichthyology. Gustav Fischer, Stuttgart, New York.
Nolf D. 1995. Studies on fossil otoliths - The state of the art. In: Secor D.H., Dean J.M., Campana S.E. (eds), Recent Developments in Fish Otolith Research. University of South Carolina Press, Columbia, SC, pp. 513-544.

Pappalardo A.M., Ferrito V., Messina A., Guarino F., Patarnello T., de Pinto V., Tigano C. 2008. Genetic structure of the killifish Aphanius fasciatus, Nardo 1827 (Teleostei, Cyprinodontidae), results of mitochondrial DNA analysis. J. Fish Biol. 72: 1154-1173.

Popper A.N., Ramcharitar J.U., Campana S.E. 2005. Why otoliths? Insights from inner ear physiology and fisheries biology. Mar. Fresh. Res. 56: 497-504.

Posada D. 2008. jModelTest: Phylogenetic Model Averaging. Mol. Biol. Evol. 25: 1253-1256.

Reichenbacher B., Sienknecht U. 2001. Allopatric divergence and genetic diversity of Recent Aphanius iberus and fossil Prolebias meyeri (Teleostei, Cyprinodontidae) from southwest and western Europe, as indicated by otoliths. Geobios 34: 69-83.

Reichenbacher B., Feulner G.R., Schulz-Mirbach T. 2009a. Geographic Variation in Otolith Morphology Among Freshwater Populations of Aphanius dispar (Teleostei, Cyprinodontiformes) from the Southeastern Arabian Peninsula. J. Morph. 270: 469-484.

Reichenbacher B., Kamrani E., Esmaeili H.R., Teimori A. 2009 b. The endangered cyprinodont Aphanius ginaonis (Holly, 1929) from southern Iran is a valid species: evidence from otolith morphology. Environ. Biol. Fish. 86: 507-521.

Reichenbacher B., Sienknecht U., Küchenhoff H., Fenske N. 2007. Combined otolith morphology and morphometry for assessing taxonomy and diversity in fossil and extant killifish (Aphanius, $\dagger$ Prolebias). J. Morph. 268: 898-915.

Rocco L., Ferrito V., Costagliola D., Marsilio A., Pappalardo A.M., Stingo V., Tigano C. 2007. Genetic divergence among and within four Italian populations of Aphanius fasciatus (Teleostei, Cyprinodontiformes). It. J. Zool. 74: 371-379.

Ronquist F., Huelsenbeck J.P. 2003. MrBayes 3, Bayesian phylogenetic inference under mixed models. Bioinform. 19: 1572-1574.

Ronquist F., Huelsenbeck J.P., Van der Mark P. 2005. MrBayes 3.1 Manual. Available at http://mrbayes.csit.fsu.edu/ Accessed date May 2007.

Rozas J., Sánchez-Delbarrio J.C., Messeguer X., Rozas R. 2003. DnaSP, DANN polymorphism analyses by the coalescent and other methods. Bioinform. 19: 2496-2497.

Schwarzhans W., Bratishko A. 2011. The otoliths from the middle Paleocene of Luzanivka (Cherkasy district, Ukraine). N. Jb. Geol. Pal. Abh. 261: 83-110.

Shimodaira H., Hasegawa H. 1999. Multiple comparisons of loglikelihoods with applications to phylogenetic inference. Mol. Biol. Evol. 16: 1114-1116.

Smale M.J., Watson G., Hecht T. (eds). 1995. Otolith atlas of southern African marine fishes (Ichthyological Monographs). J.L.B. Smith Institute of Ichthyology, Grahamstown.

Sollner-Webb B., Mougey E.B. 1991. News from the nucleolus: rRNA gene expression. Trends Biochem. Sci. 16: 58-62.

SPSS Inc. 2011. SPSS. Ver. 19.0. Base. Chicago, IL: SPSS, Inc.

Stepien C. A., Rosenblatt R.H., Bargmeyer B.A. 2001. Phylogeography of the spotted sand bass, Paralabrax maculatofasciatus: divergence of Gulf of California and Pacific coast populations. Evolution 55: 1852-1862.

Stransky C., Baumann H., Fevolden S.E., Harbitz A., Høie H., Nedreaas K.H., Salberg A.B., Skarstein T. 2008. Separation of Norwegian coastal cod and Northeast Arctic cod by outer otolith shape analysis. Fish. Res. 90: 26-35.

Swofford D.L. 2003. PAUP*: Phylogenetic analysis using parsimony (* and other methods), version 4.0b10. Sinauer Associates, Sunderland, MA.

Tamura K., Nei M. 1993. Estimation of the number of nucleotide substitutions in the control region of mitochondrial DNA in humans and chimpanzees. Mol. Biol. Evol. 10: 512-526.

Teimori A., Schulz-Mirbach T., Esmaeili H.R., Reichenbacher B. 2012a. Geographical differentiation of Aphanius dispar (Teleostei: Cyprinodontidae) from Southern Iran. J. Zool. Sys. Evol. Res. 50: 289-304.

Teimori A., Jawad L.A.J., Al-Kkarusi L.H., Al-Mamry J.N., Reichenbacher B. 2012b. Late Pleistocene to Holocene diversification and zoogeography of the Arabian killifish Aphanius dispar inferred from otolith morphology. Sci. Mar. 76: 637-645. 
Tigano C., Ferrito V., Nicosia R. 1999. Morphological analysis of the pharyngeal jaws in two populations of Aphanius fasciatus Valenciennes, 1821 (Teleostei: Cyprinodontidae). J. Morph. 241: $107-114$

Tigano C., Ferrito V., Adorno A., Mannino M.C., Mauceri A. 2001. Pharyngeal and oral jaw differentiation in five populations of Aphanius fasciatus (Teleostei, Cyprinodontidae). It. J. Zool. 68: 201-206.

Tigano C., Canapa A., Ferrito V., Barucca M., Arcidiacono I., Olmo E. 2004. Osteological and molecular analysis of three Sicilian populations of Aphanius fasciatus (Teleostei, Cyprinodontidae). It. J. Zool. 71: 107-113.

Tigano C., Canapa A., Ferrito V., Barucca M., Arcidiacono I., Deidon A., Schembri P.J., Olmo E. 2006. A study of osteological and molecular differences in populations of Aphanius fasciatus Nardo, 1827, from the central Mediterranean (Teleostei, $\mathrm{Cy}$ prinodontidae). Mar. Biol. 149: 1539-1550.

Torres G.J., Lombarte A., Morales-Nin B. 2000. Sagittal otolith size and shape variability to identify intraspecific differences in three species of the genus Merluccius. J. Mar. Biol. Ass. U.K. 80: 333-342.

Torres-Machorro A.L., Hernandez R., Cevallos A.M., Lopez-Villasenor I. 2010. Ribosomal RNA genes in eukaryotic microorganisms: witnesses of phylogeny? FEMS Microbiol. Rev. 34: 59-86.

Triantafyllidis A., Leonardos I., Bista I., Kyriazis I.D., Stoumboudi M.T., Kappas I., Amat F., Abatzopoulos T.J. 2007. Phylogeography and genetic structure of the Mediterranean killifish Aphanius fasciatus (Cyprinodontidae). Mar. Biol. 152: 1159-1167.

Tuset V.M., Lombarte A., Assis C. 2008. Otolith atlas for the western Mediterranean, north and central eastern Atlantic. Sci. Mar. 72S1: 7-198.

Vignon M., Morat F. 2010. Environmental and genetic determinant of otolith shape revealed by a nonindigenous tropical fish. Mar. Ecol. Prog. Ser. 411: 231-241.
Villwock W. 1994. On micropopulations in fish and their effects on differentiation and speciation. In: Remmer H. (ed.), Minimum Animal Populations. Ecol. Stud. 106. Springer, Berlin, pp. 51-65.

Volpedo A.V., Cirelli A.F. 2006. Otolith chemical composition as a useful tool for sciaenid stock discrimination in the southwestern Atlantic. Sci. Mar. 70: 325-334.

Volpedo A.V., Echeverría D.D. (eds) 2000. Catálogo y claves de otolitos para la identificación de peces del Mar Argentino. 1. Peces de importancia comercial. Editorial Dunken, Buenos Aires.

Wildekamp R.H. 1993. The genus Aphanius Nardo. In: Watters B.R. (ed.), A World of Killies, Atlas of the Oviparous Cyprinodontiform Fishes of the World. American Killifish Association, Mishawaka, IN., pp. 19-67.

Williams D.A., Brown S.D., Crawford D.L. 2008. Contemporary and historical influences on the genetic structure of the estuarine-dependent Gulf killifish Fundulus grandis. Mar. Ecol. Prog. Ser. 373: 111-121.

Wilson A.C., Cann R.L., Carr S.M., Geroge M., Gyllensten U.B., Helm-Bychowski K.M., Higuchi R.G., Palumbi S.R., Prager E.M., Sage R.D., Stoneking M. 1985. Mitochondrial DNA and two perspectives on evolutionary genetics. Biol. J. Linn. Soc. 26: $375-400$.

Woods R.J., Macdonald J.I., Crook D.A, Schmidt D.J., Hughes J.M. 2010. Contemporary and historical patterns of connectivity among populations of an inland river fish species inferred from genetics and otolith chemistry. Can. J. Fish. Aquat. Sci. 67: 1098-1115.

Scient. ed.: I. Palomera.

Received October 19, 2012. Accepted March 15, 2013.

Published online May 2, 2013. 